\title{
Significance of Electronic Word of Mouth (e-WOM) in Opinion Formation
}

\author{
Javaria Khalid $^{1}$, Aneela Abbas ${ }^{2}$ \\ Muhammad Qasim Mahmood ${ }^{4}$, Arslan Tariq ${ }^{6}$ \\ Madiha Khatoon ${ }^{7}$, Samreen Azhar ${ }^{9}$ \\ Department of Computer Science and IT \\ University of Lahore \\ Gujrat Campus, Pakistan 1, 2, 4, 6, 7,9
}

\author{
Rida Akbar ${ }^{3}$, Rafia $^{5}$, Ayesha Akbar ${ }^{8}$, Asra Meer $^{10}$, \\ Muhammad Junaid Ud Din ${ }^{11}$ \\ University of the Punjab, Pakistan ${ }^{3}$ \\ University of Gujrat, Pakistan ${ }^{8}$ \\ Gift University, Pakistan 5,10 \\ Pakistan Engineering Council (Electrical Engineering) ${ }^{11}$
}

\begin{abstract}
In the realm of interconnected digital world, social ranking systems are readily used in different sections of society, for several reasons. The private and public sectors both are making use of social ranking systems as a tool to engineer human behavior, and crafting a digitally stimulated social control. Online reviews and ratings are one of the significant marketing strategies of online sellers to steer out consumers' opinion and ultimately their purchasing decisions. Buyers usually go through these reviews and ratings while purchasing online product or hiring online services. Online consumer reviews, recommendations for product and services, and peer viewpoints play a significant role in the customer's opinion formation. Different online forums of product reviews, ratings and recommendations differ in their objectives, functions, and characteristics. This paper focuses upon a systematic literature review and comparative study of the influence the positive and negative reviews and ratings of the products, automobile services, movies, restaurants, products and services on OLX \& eBay, etc. have on opinion formation. Moreover, how these reviews influence others opinions of buying and using the products, services and apps will be analyzed.
\end{abstract}

Keywords-Component; E-WOM (Electronic word of mouth); opinion formation; positive reviews; negative reviews

\section{INTRODUCTION}

The growth of online social platform has radically altered the way people find information about other people, products and services and how people interact with others [1]. Social media, the internet-based digital and social networking platforms, offer users the opportunities to link with others, form groups, interact with people, produce messages, share content, write comments, respond and follow one another in a cybernetic community" [2]. In the era of social media, individuals generate and circulate content and try to have a thoroughgoing impact upon masses. Consequently, the information traded in digital social networking platforms is termed by many as "user-generated content" [3].

Electronic word-of-mouth communication (e-WOM) is defined by Goldsmith (2006) as "word-of-mouth communication on the Internet, it can be dispersed by social applications as online forums, reviews sites, and social networking sites". It is considered an indispensable source of information that affects human behavior. Customers are encouraged to give their reviews of the product since 1995 in a large number of 10 million and it was enabled by Amazon.com [4]. Online word-of-mouth (e-WOM) platforms have become one of the most vital sources of information for modern consumers. A large variety is given such as "explosion in the number, range, completeness, and general availability of online reviews" [5]. Researchers found that e-WOM had a positive impact on the decision of the consumers. It affected the opinions of the people of different ages and genders and helped them in making further decisions. For making buying and usage decisions, advertisement is highly preferred by the people rather than word of mouth but for opinion formation, word of mouth is considered more reliable. A bad experience can develop a bad impression of a product which results in negative impression whereas positive word of mouth can give a positive imprint of products and services [6].

As per a report by a research firm $70 \%$ of consumer's favor and trust online product reviews [7]. Online views affect consumer choices in different ways. Airlines, telephone companies, resorts, movies, products and services all are adjudged by online reviews and recommendations. Moreover, 5,000 shoppers across five countries identified their three frequently used resources they use for opinion formation. Online reviews on retailer websites $(52 \%)$ were considered as one of these three frequently used informative resources. Furthermore, recommendations by friends and family members (49\%) and advices from store employees (12\%) were also critical in influencing the opinions of the masses [8].

In this research paper, will analyze the literature review of different services, products, and applications along with their positive and negative reviews and how they influence upon opinion formation of an individual.

\section{Literature Study Related to Products, Services AND APPS REVIEWS}

Smita Dayal (2016) proposes that companies put online social platforms in the zones of societal advertising, communal client associations and organizations, and innovative professional mock-ups. The social media is an eminent forum, which help businesses to work and interact with prospect clients, personnel and other investors [9]. The buying decision of a person is strongly affected by a number of available reviews on social platforms that can be either good or bad. Visual, descriptive and collective reviews have a 
noticeably optimistic effect on purchasers' decisions [10], hence the apparent menace of clients can be abridged to a great extent. As suggested by Prabha Kiran and Vasantha S. (2015) E-WOM can instigate the buying intents of consumers while they purchase online [11] [12].

Following tables (I-V) give a comprehensive insight of the online products, services and apps reviews and ratings and how they influence the opinions and viewpoints of the other people.

These tables represent comparative literature study of different products like EBAY and OLX as it is elaborated in Tables I and II. Description, results and methodology are also explained in different tables of automobiles, Movies and restaurant rating systems respectively in Tables III, IV and V.

TABLE. I. COMPARATIVE STUdy OF ONLINE PRODUCTS REVIEWS AND RATINGS

\begin{tabular}{|c|c|c|c|c|}
\hline \multirow[t]{2}{*}{ Paper title } & \multirow[t]{2}{*}{ Description } & \multicolumn{2}{|l|}{ Results } & \multirow[t]{2}{*}{ Methodology } \\
\hline & & Factors & Statistical Results & \\
\hline $\begin{array}{l}\text { Research on Product } \\
\text { Review Analysis and } \\
\text { Spam Review Detection } \\
\text { (2017) } \\
{[13]}\end{array}$ & $\begin{array}{ll}\text { - } & \text { Product Review } \\
\text { - } & \text { Preprocessing } \\
\text { - } & \text { Sentime removal } \\
\text { - } & \text { Spam Review } \\
\text { - } & \text { Feature Tagging } \\
\text { - } & \text { Popularity Analysis } \\
\text { - } & \text { Results }\end{array}$ & $\begin{array}{l}\text { 1. Removal of special characters } \\
\text { and punctuations, like (\#, ^, *, } \\
\text { etc.) } \\
\text { 2. Removal of irrelevant and } \\
\text { malicious curse words } \\
\text { 3. Removal of repeating letters } \\
\text { (stemming) } \\
\text { E.g. ("happyyy, hungryyy") } \\
\text { 4. Abbreviations extending }\end{array}$ & Not Applicable & Product Rating \\
\hline $\begin{array}{l}\text { Brand awareness } \\
\text { research } \\
(2016) \\
{[14]}\end{array}$ & $\begin{array}{l}\text { The purpose is to know: } \\
\text { The level of brand understanding } \\
\text { of the case company } \\
\text { Online travel agency TravelBird. } \\
\text { - How customers view the case } \\
\text { company and either they see it as } \\
\text { an appealing brand. }\end{array}$ & $\begin{array}{l}\text { The important factors when buying } \\
\text { travel products. } \\
\text { - The Frequency of purchase. } \\
\text { - The type of travel product. } \\
\text { Living status of the } \\
\text { respondents. } \\
\text { The awareness levels of the } \\
\text { logo, brand name, and } \\
\text { Images of Travel Bird }\end{array}$ & Not Applicable & $\begin{array}{l}\text { In this study the variables are: } \\
\text { Higher Purchase Rate: } \\
\text { - } \quad \text { Travel Product. } \\
\text { - } \quad \text { Good Quality. } \\
\text { - } \quad \text { Under } 25 \text { age. } \\
\text { - } \quad \text { Advertisement. } \\
\text { - } \quad \text { Living Status. }\end{array}$ \\
\hline $\begin{array}{l}\text { An Analysis Study of } \\
\text { Improving Brand } \\
\text { Awareness and Its } \\
\text { Impact on Consumer } \\
\text { Behavior Via Media in } \\
\text { North Cyprus(2015) } \\
\text { [15] }\end{array}$ & $\begin{array}{l}\text { It accentuates upon the } \\
\text { significance of these dimensions } \\
\text { (brand knowledge, brand fidelity, } \\
\text { brand image, and end-users } \\
\text { behavior) it influences consumer's } \\
\text { discernment. }\end{array}$ & $\begin{array}{l}\text { Brand Loyalty } \\
\text { - } \quad \text { Brand Image } \\
\text { - } \quad \text { Media } \\
\text { Dependent Behavior } \\
\text { - } \quad \text { Brand Awareness }\end{array}$ & $\begin{array}{r}\text { T-Test: } \\
0.322 \\
0.395 \\
0.346 \\
0.334\end{array}$ & $\begin{array}{l}\text { A linear regression model is } \\
\text { highlighted and discussed. The } \\
\text { maximum coefficient is } \\
\text { acquired by Brand Image } \\
\text { which is equivalent to } 0.395 \\
\text { with maximum } t \text {-statistic } \\
(6.583) \text {. }\end{array}$ \\
\hline
\end{tabular}

TABLE. II. COMPARATIVE STUDY OF EBAY AND OLX ONLINE REVIEWS AND RATINGS

\begin{tabular}{|c|c|c|c|c|}
\hline \multirow[t]{2}{*}{ Paper title } & \multirow[t]{2}{*}{ Description } & \multicolumn{2}{|l|}{ Results } & \multirow[t]{2}{*}{ Methodology } \\
\hline & & Factors & Statistical Results & \\
\hline $\begin{array}{l}\text { E-bay or } \\
\text { Craigslist?: } \\
\text { Explaining } \\
\text { Users' } \\
\text { Choice of } \\
\text { Online } \\
\text { Transaction } \\
\text { Community } \\
{[16]}\end{array}$ & $\begin{array}{l}\text { - It examines consumers' base for selecting a } \\
\text { specific virtual transaction community. Based } \\
\text { on transaction cost economics (TCE), we } \\
\text { assume business expenses influence buyers' } \\
\text { choice. } \\
\text { - We look at dissimilar institutional mechanisms } \\
\text { and compare them eBay's well repute systems } \\
\text { vs. Craigslist's face-to-face native business. } \\
\text { - Resource-based view (RBV) model states that } \\
\text { the mass of target spectators in online business } \\
\text { municipal troubles and it has an influence upon } \\
\text { decision. }\end{array}$ & $\begin{array}{l}\text { - Institutional } \\
\text { mechanisms } \\
\text { - Assist in trust- } \\
\text { building } \\
\text { - Eradicate } \\
\text { intermediate } \\
\text { such as PayPal } \\
\text { - No contract fee } \\
\text { - Free shipping } \\
\text { cost }\end{array}$ & ----- & $\begin{array}{l}\text { - EBay's recognized systems provides a } \\
\text { safe online business atmosphere, } \\
\text { while Craigslist's face-to-face } \\
\text { indigenous operation causes } \\
\text { consumers' security apprehension. } \\
\text { - Enlarging RBV study, higher viewers } \\
\text { of an item will create a higher } \\
\text { purchase on eBay than on Craigslist. } \\
\text { - It summarizes and differentiates two } \\
\text { kinds of the business community. }\end{array}$ \\
\hline
\end{tabular}


TABLE. III. COMPARATIVE STUdy OF AUtOMOBILES ONLINE REVIEWS AND RATINGS

\begin{tabular}{|c|c|c|c|c|}
\hline \multirow[t]{2}{*}{ Paper title } & \multirow[t]{2}{*}{ Description } & \multicolumn{2}{|l|}{ Results } & \multirow[t]{2}{*}{ Methodology } \\
\hline & & Factors & Statistical Results & \\
\hline $\begin{array}{l}\text { Brand Awareness and } \\
\text { Customers } \\
\text { Satisfaction towards } \\
\text { OLA Cabs in } \\
\text { Bengaluru North and } \\
\text { South Region } \\
\text { (2015) [17] }\end{array}$ & $\begin{array}{l}\text { - Firstly, awareness of brand } \\
\text { knowledge is important. } \\
\text { End user's satisfaction relates to } \\
\text { their emotional reaction correlated } \\
\text { with products and services. } \\
\text { It investigates brand knowledge } \\
\text { and consumers' liking OlaCabs. }\end{array}$ & $\begin{array}{ll}\text { - } & \text { Convenient } \\
\text { - } & \text { Brand } \\
\text { - } & \text { Quick and Safe } \\
\text { - } & \text { Easy to Book } \\
\text { - } & \text { At time Pick-up and Drop }\end{array}$ & $\begin{array}{ll}- & \text { Chi- } \\
& \text { Squrae: } 182.731 \\
- & \text { Degree of } \\
& \text { Freedom: } 4\end{array}$ & $\begin{array}{l}\text { The methodology which is } \\
\text { used is Chi-square, Asymy. } \\
\text { Sig and Degree of freedom. }\end{array}$ \\
\hline $\begin{array}{l}\text { A study of customer } \\
\text { satisfaction level of } \\
\text { ola and uber paid taxi } \\
\text { services with special } \\
\text { reference to Pune city } \\
\text { (2018) } \\
{[18]}\end{array}$ & $\begin{array}{l}\text { Observing about consumers' level } \\
\text { of liking and satisfaction of the } \\
\text { folks who are using OLA and } \\
\text { UBER cabs in Pune city. } \\
\text { Learning and studying different } \\
\text { aspects like pricing, market share, } \\
\text { revenue models, app convenience, } \\
\text { etc. }\end{array}$ & $\begin{array}{ll}\text { Taxi Preferred due to these } \\
\text { motivational factors: } \\
\text { - } & \text { Satisfaction Level } \\
\text { - } & \text { Complaints } \\
\text { - } & \text { Recommendation } \\
\text { - } & \text { Discount } \\
\text { - } & \text { Payment options }\end{array}$ & --- & $\begin{array}{l}\text { The questionnaire and } \\
\text { interviews are conducted using } \\
\text { OLA and UBER. } \\
\text { RESULTS: } \\
\text { - "Safety" as the most } \\
\text { important factor while } \\
\text { choosing OLA/UBER. } \\
\text { - 54\% of respondents favor it. }\end{array}$ \\
\hline
\end{tabular}

TABLE. IV. COMPaRATIVE STUdy of MOVIES ONLINE REVIEWS AND RATINGS

\begin{tabular}{|c|c|c|c|c|}
\hline \multirow[t]{2}{*}{ Paper title } & \multirow[t]{2}{*}{ Description } & \multicolumn{2}{|l|}{ Results } & \multirow[t]{2}{*}{ Methodology } \\
\hline & & Factors & Statistics & \\
\hline $\begin{array}{l}\text { Dynamic Effects } \\
\text { Among Movie } \\
\text { Ratings, Movie } \\
\text { Revenues, and } \\
\text { Viewer } \\
\text { Satisfaction. } \\
\text { [19] }\end{array}$ & $\begin{array}{l}\text { - It attempts to explore how ratings of a } \\
\text { movie from proficient critics, } \\
\text { proletarian communities, and spectators } \\
\text { themselves have an impact upon key } \\
\text { movie performance measures. } \\
\text { - They also come across that high } \\
\text { advertising generates high ratings and } \\
\text { movie revenues. } \\
\text { - This research draws attention to how } \\
\text { spectators' viewing, rating histories and } \\
\text { movie communities' collective view } \\
\text { describes viewer satisfaction. }\end{array}$ & $\begin{array}{ll}\text { - } & \text { Six genres } \\
- & \text { Sequel } \\
\text { - } & \text { Eight major } \\
& \text { studio } \\
& \text { distribution } \\
- & \text { MPAA rating } \\
\text { - } & 7 \text { major holiday } \\
& \text { release }\end{array}$ & \begin{tabular}{|l}
$-\quad$ Six genres \\
Thriller $(35,14 \%)$, \\
romance $(25,10 \%)$, action \\
$(51,21 \%)$, drama $(50$, \\
$20 \%)$, comedy $(74,30 \%)$, \\
animation $(11,4 \%)$ \\
- Holiday release \\
Theatre release $(34,14 \%)$, \\
video release $(36,15 \%)$
\end{tabular} & $\begin{array}{l}\text { - This study reveals that ratings are } \\
\text { linked with movie performance, as } \\
\text { calculated by both movie revenues } \\
\text { and spectator satisfaction. } \\
\text { - For movie rental companies, movie } \\
\text { ratings are an effectual calculation of } \\
\text { a member's satisfaction. } \\
\text { - Our movie-level data examination } \\
\text { entails that marketers should assign } \\
\text { more ad dollars to movies that gather } \\
\text { early high ratings by professional } \\
\text { reviewers. }\end{array}$ \\
\hline
\end{tabular}

TABLE. V. COMPARATIVE STUdy OF RESTAURANTS ONLINE REVIEWS AND RATINGS

\begin{tabular}{|c|c|c|c|c|}
\hline \multirow[t]{2}{*}{ Paper title } & \multirow[t]{2}{*}{ Description } & \multicolumn{2}{|l|}{ Results } & \multirow[t]{2}{*}{ Methodology } \\
\hline & & Factors & Statistical Results & \\
\hline $\begin{array}{l}\text { Reviews, } \\
\text { Reputation, } \\
\text { and Revenue: } \\
\text { The Case of } \\
\text { Yelp.com } \\
\text { [20] }\end{array}$ & $\begin{array}{l}\text { - Do online customer reviews } \\
\text { affect restaurant demand? } \\
\text { - This question is explored by } \\
\text { using a fresh dataset } \\
\text { mingling reviews from the } \\
\text { website Yelp.com }\end{array}$ & $\begin{array}{ll}\text { - } & \text { Revenue (\$) } \\
- & \text { Rating } \\
- & \text { Reviews } \\
- & \text { Elite Reviews } \\
\text { - } & \text { Friends of Reviewers }\end{array}$ & $\begin{array}{l}\text { Reviews: } \\
\text { Mean: } 3.6 \\
\text { Obs: } 14,593 \\
\text { Standard Deviation: } \\
0.9\end{array}$ & $\begin{array}{l}\text { The impact of customers' reviews: } \\
\text { 1. A one-star boost in Yelp rating } \\
\text { leads to a 5-9 percent amplify in } \\
\text { revenue. } \\
\text { 2. Customers are more receptive to } \\
\text { more noticeable quality changes. } \\
\text { 3. Customers react more strongly } \\
\text { when a rating holds more } \\
\text { information. }\end{array}$ \\
\hline $\begin{array}{l}\text { An analysis of } \\
\text { online reviews of } \\
\text { upscale Iberian } \\
\text { restaurants } \\
{[21]}\end{array}$ & $\begin{array}{l}\text { - It examines the relationships } \\
\text { between service quality, food } \\
\text { quality, consumer satisfaction, } \\
\text { and consumer retention } \\
\text { restaurants. } \\
\text { - A questionnaire-based survey } \\
\text { was held among } 400 \text { students } \\
\text { served at } 10 \text { limited-service } \\
\text { restaurants. }\end{array}$ & $\begin{array}{cl}\text { Independent Variable: } \\
\text { - } & \text { Reliability } \\
\text { - } & \text { Responsiveness } \\
\text { - } & \text { Assurance } \\
\text { - } & \text { Empathy } \\
\text { - } & \text { Food Quality } \\
\text { Dependent Variable: } \\
\text { - } \quad \text { Customer Satisfaction }\end{array}$ & ----- & $\begin{array}{l}\text { - The purpose of the study was to } \\
\text { scrutinize the connection between } \\
\text { service and food quality } \\
\text { dimensions and consumer } \\
\text { satisfaction. } \\
\text { - The study supposed that both } \\
\text { service and food quality would } \\
\text { have an affirmative impact on } \\
\text { consumer satisfaction, which in } \\
\text { turn would certainly influence } \\
\text { consumer retention. }\end{array}$ \\
\hline
\end{tabular}




\begin{tabular}{|c|c|c|c|c|}
\hline $\begin{array}{l}\text { Online Customer } \\
\text { Reviews on } \\
\text { Restaurants and } \\
\text { Expert Opinions: } \\
\text { An Integrated } \\
\text { Approach } \\
{[22],[23]}\end{array}$ & $\begin{array}{l}\text { - Online reviews have an } \\
\text { impact on consumers' } \\
\text { restaurant choices. } \\
\text { - Online reviews are the most } \\
\text { prominent when it comes to } \\
\text { consumers' decision making. } \\
\text { - This study attempts to explore } \\
\text { the relative significance of } \\
\text { online reviews in customers' } \\
\text { restaurant choices. }\end{array}$ & ----- & $\begin{array}{l}\text { In Customer satisfaction: } \\
\text { - Food Quality is Ranked } \\
1^{\text {st }} \text { with Mean: } 1.8 \\
\text { SD: } 1.518 . \\
\text { - Restaurant Rating is } \\
\text { ranked with } \\
\text { Mean: } 4.05 \\
\text { S.D: } 1.646\end{array}$ & $\begin{array}{l}\text { - This research endeavors to fill the } \\
\text { gap in terms of the association } \\
\text { between online reviews and } \\
\text { restaurant characteristics that are } \\
\text { professed as significant aspects } \\
\text { while choosing a restaurant. } \\
\text { - The results of the study } \\
\text { accentuate that food quality and } \\
\text { overall restaurant rating of the } \\
\text { restaurant have the maximum } \\
\text { influence on consumer's } \\
\text { restaurant choices. }\end{array}$ \\
\hline $\begin{array}{l}\text { The Impact of E- } \\
\text { Word-of-Mouth } \\
\text { on the Online } \\
\text { Popularity of } \\
\text { Restaurants: A } \\
\text { Comparison of } \\
\text { Consumer } \\
\text { Reviews and } \\
\text { Editor Reviews } \\
\text { [24][25] }\end{array}$ & $\begin{array}{l}\text { - It determines the number of } \\
\text { online reviews consumers } \\
\text { partake a constructive and } \\
\text { positive impact upon } \\
\text { restaurant performance. } \\
\text { - A cafeteria that has a } \\
\text { superiority certificate and a } \\
\text { good number of reviews } \\
\text { promote income and } \\
\text { popularity contrasted with the } \\
\text { other one. }\end{array}$ & $\begin{array}{l}\text { Independent Variables: } \\
\text { - } \quad \text { No. of Reviews } \\
\text { - } \quad \text { Restaurant Ranking } \\
\text { Control Variables: } \\
\text { - } \quad \text { Food } \\
\text { - } \quad \text { Service } \\
\text { - } \quad \text { Atmosphere } \\
\text { Dependent variables: } \\
\text { - } \quad \text { Total sales } \\
\text { - } \quad \text { No of customers } \\
\text { - } \quad \text { Average check }\end{array}$ & $\begin{array}{l}\text { The number of reviews: } \\
\text { Mean: } 113.36 \\
\text { S.D: } 104.03\end{array}$ & $\begin{array}{l}\text { - Online consumer remarks } \\
\text { determine the significant role in } \\
\text { E-WOM and young ones choose } \\
\text { to use online platforms instead of } \\
\text { outdated offline media. } \\
\text { - Consequently, clients who have } \\
\text { no dining experience with the } \\
\text { restaurants, they should } \\
\text { significantly make use of } \\
\text { platforms like Facebook, Twitter, } \\
\text { YouTube, and Instagram. }\end{array}$ \\
\hline
\end{tabular}

\section{SigNifiCANCE OF STUDY}

Online reviews have now become quite prevalent, influential and a key source of obtaining knowledge and information. Many types of researchers have organized influential studies to comprehend two main queries: "why do consumers have faith and then use the information which is given by comparatively unfamiliar and unidentified persons" and "how do consumers infer the reviews to obtain the information they wish for and are ready to put faith into it". It includes archival data gathered from websites like Amazon.com and Ebay.com and attitudinal data which is gathered using surveys and experiments [26].

In recent times, Mudambi and Schuff (2010) investigated consumers' perception of reviewing assistance while deriving data from Amazon.com. The authors experimented on the impacts of many variables, like the extent of the textual piece in reviews and numerical ratings of products, on customers' discernment of reviews. Quite intriguingly, the authors detected that reviews having acute affirmative or negative ratings are typically found unsupportive by other persons [27]. The reviews by the consumer had an influence on sales of video games and uncovered that negative reviews generally have a better impact on sales, and the number of reviews linked with a product is usually considered as heuristics by customers to measure the common features of the product [28].

Researchers consider that in online shopping mall, online positive and negative reviews of the products are sold [29]. It is indicated that online reviews are appraisal data of products and services put on third-party and trader's sites, which is shaped by the consumers and shape up the prospect consumers' behavior. Online reviews are evaluation information about the various features of customer commodities [30]. On the whole, a quantitative study of how online reviews influence consumer purchasing conduct can be changed into a study of how online reviews influence merchandise sales. Thorough research on online reviews and movie box office revenues, various researchers discovered employing sales to determine customer's buying behaviors was viable in the quantitative measure [31].

Hence, numerous findings demonstrate how online reviews influence consumers purchasing behavior through monthly commodity deal proceedings. Watson, the originator of behavioral psychology, presented the "stimulus-response" model. Based on it, Mehrabian proposed the consumer behavior model, Stimulus-Organism- Response Model (SOR model) [32] as shown in Fig. 1.

In Fig. 1, SOR model depicts that the situation can stimulate purchasers' mind-set and then affects consumer conduct, having the influence of online reviews on buyers' judgment and purchase decision. Below are given Different applications and there positive and negative reviews are elaborated in tabular form and how they impact customer decision making, is discussed.

Many Online Doctor Service Apps and their positive and negative reviews are discussed in Table VI. A survey was conducted about online rating and score of the app and patient reviews and it included responses from more than 800 people. The main responses concluded the following points:

- $74.6 \%$ of respondents had investigated doctors, dentists, or medical care online.

- $69.9 \%$ said an affirmative online standing is extremely or really important in choosing a healthcare supplier.

- $51.8 \%$ of patients who had submitted negative online reviews about a medical practice had never been in touch with the address of their concerns.

- Patient satisfaction doubles when a negative review is addressed [33].

NRC Health's research discovered that $92.4 \%$ of clients make use of online reviews to get direction about most of their everyday purchasing decisions. 

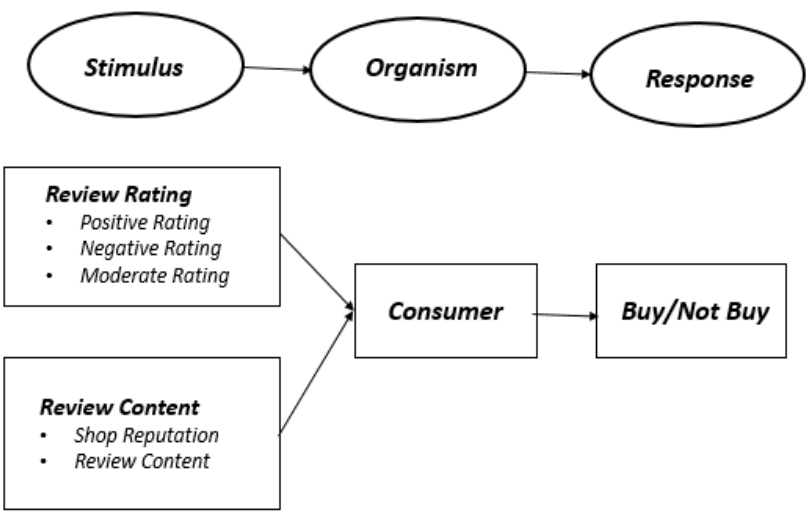

Fig. 1. SOR Model [32].

As said by a Local Consumer Review Survey organized by Bright Local, 97\% consumers from the age group of (18-34) study online reviews to judge a local business [34].

Many Online Lawyer Service Apps and their positive and negative reviews are discussed in Table VII. Reviews permit customers to acquire real feedback about the firm to determine if it's good and fit for their needs. A report from Reviewtrackers.com determines that almost $83 \%$ of people checked lawyer reviews at the initial stage to find an attorney. In the 2015 survey done by Bright Local with 2,354 participants was found that $92 \%$ people are concerned with online reviews for judging the products and services. In a 2013, A survey of 1,046 individuals was conducted by Zen desk and it concluded that positive reviews affect $\mathbf{9 0 \%}$ of the participant's decisions [37].
Google's search engine algorithm gives preference to legal websites having positive reviews among a diversity of platforms, putting websites of law firm having more reviews higher in the search results.

- $90 \%$ customers consult reviews before going to or communicating a law firm.

- $84 \%$ of clients have reliance and confidence upon online reviews.

- $74 \%$ of respondents say that positive reviews develop believe and trust upon native law firms [38].

Online Automobile Service Apps and their positive and negative reviews are discussed in Table VIII. As everybody knows, Uber is comfortable to ride but most people give them less than five-star rating [39]. Due to the negative rating, the uber driver will get fewer rides and earn less than other drivers who have positive ratings and reviews.

But a new study from New York University found that "the value of rating systems like Uber's decreases over time because of public pressure to give another person a high rating, which continually pushes the average up and up until it becomes fairly irrelevant hence unreliable" [40].

After listing different reviews of lawyers, doctors and automobiles apps, the last Table IX represents names of different online home services applications and their ratings and positive or negative reviews. Furthermore, how these reviews and ratings influence the people opinions and decisions are also evaluated in the above given tables.

TABLE. VI. ONLINE DOCTOR SERVICES APP REVIEW

\begin{tabular}{|c|c|c|c|c|}
\hline $\begin{array}{l}\text { App Name } \\
{[33][34][35]}\end{array}$ & Rating & Positive Review & Negative Review & $\begin{array}{l}\text { Impact Upon } \\
\text { Customer Decision }\end{array}$ \\
\hline \multirow{2}{*}{ I Online Doctor } & \multirow{2}{*}{4.3} & "Excellent Application to find and consult with best doctors" & $\begin{array}{l}\text { "It's a waste of time fake online } \\
\text { doctor" }\end{array}$ & Yes \\
\hline & & $\begin{array}{l}\text { "I refer to my child's pediatric } \\
\text { Its balance between my work and family" }\end{array}$ & "Very immoral customer service" & Yes \\
\hline \multirow{2}{*}{ Consult By Doc Dr } & \multirow{2}{*}{5.0} & $\begin{array}{l}\text { "It is very beneficial, Easy to cooperate between Doctor and } \\
\text { Patient" }\end{array}$ & $\begin{array}{l}\text { "No one attends call even after } \\
\text { entering your credit card detail" }\end{array}$ & Yes \\
\hline & & $\begin{array}{l}\text { "Best online doctor consultation app accomplished by a team } \\
\text { of expert doctors" }\end{array}$ & "No Wicked Comments" & Yes \\
\hline \multirow{2}{*}{$\begin{array}{l}\text { Call Doc App - } \\
\text { Consult Indian } \\
\text { Doctors Online }\end{array}$} & \multirow{2}{*}{4.8} & "Best online consultation app for both patients and doctors" & ---- & Yes \\
\hline & & Excellent & --- & Yes \\
\hline \multirow{2}{*}{$\begin{array}{l}\text { My Live Doctors - } \\
\text { Online Doctor } \\
\text { Consultation }\end{array}$} & \multirow{2}{*}{4.0} & "Great app to provide medical help remotely" & $\begin{array}{l}\text { "Fraud app hai. Doctor ki fees } 500 \\
\text { le Liya doctor ne koi contact nahi } \\
\text { kiya" }\end{array}$ & Yes \\
\hline & & $\begin{array}{l}\text { "This is a good app. You can virtually visit the doctor } \\
\text { through video call and can communicate whenever you want" }\end{array}$ & $\begin{array}{l}\text { "May be fake app unable to register } \\
\text { as a Dr and no response from the } \\
\text { support team" }\end{array}$ & Yes \\
\hline \multirow{2}{*}{$\begin{array}{l}\text { Hello Lyf -Online } \\
\text { Doctor Consult }\end{array}$} & \multirow{2}{*}{4.5} & $\begin{array}{l}\text { "My Live Doctors is a mobile application that will help you } \\
\text { find a doctor and book a free online doctor consultation" }\end{array}$ & $\begin{array}{l}\text { "I wrote my medical condition. I } \\
\text { thought I have a reply in minute or } \\
\text { hour but am waiting" }\end{array}$ & Yes \\
\hline & & $\begin{array}{l}\text { "Helpful in times of emergencies. I had an emergency } \\
\text { situation in an unknown place, this app helped me find } \\
\text { doctors nearby" }\end{array}$ & $\begin{array}{l}\text { "Don't work. Give error message } \\
\text { every time you try to post } \\
\text { something" }\end{array}$ & Yes \\
\hline
\end{tabular}


TABLE. VII. ONLINE LAWYER SERVICES APP REVIEW

\begin{tabular}{|c|c|c|c|c|}
\hline $\begin{array}{l}\text { App Name } \\
{[36][37][38]}\end{array}$ & Rating & Positive Review & Negative Review & $\begin{array}{l}\text { Impact Upon Customer } \\
\text { Decision }\end{array}$ \\
\hline \multirow{2}{*}{$\begin{array}{l}24 \text { Justice Online } \\
\text { Lawyers and Legal } \\
\text { Services }\end{array}$} & \multirow[t]{2}{*}{5.0} & $\begin{array}{l}\text { "I strongly approve and commend to use } \\
\text { this app for all of your legal affairs \& have } \\
\text { excellent services. }\end{array}$ & "No Bad Comment" & yes \\
\hline & & That's a great app helpful for every man" & --- & yes \\
\hline \multirow{2}{*}{ Lawyers Online } & \multirow{2}{*}{4.5} & $\begin{array}{l}\text { "This is an awesome piece. It's an app ever } \\
\text { Nigerian should have, not just lawyers. } \\
\text { Wow" }\end{array}$ & "I can't open it after updating it" & Yes \\
\hline & & $\begin{array}{l}\text { "Free and helpful indeed. Keep informing } \\
\text { as you know that laws are not fixed. } \\
\text { Appreciations" }\end{array}$ & $\begin{array}{l}\text { "It's OK but it does not carry every decision of } \\
\text { the appellate courts" }\end{array}$ & Yes \\
\hline \multirow{2}{*}{$\begin{array}{l}\text { Legal Services } \\
\text { Link }\end{array}$} & \multirow{2}{*}{4.6} & "Excellent app" & $\begin{array}{l}\text { "This app was absolutely useless in the fact } \\
\text { that I was unable to search for an attorney" }\end{array}$ & yes \\
\hline & & "Outstanding App" & "Kept checking boxes that I didn't mark" & Yes \\
\hline \multirow{2}{*}{ Got My Legal Help } & \multirow{2}{*}{4.4} & $\begin{array}{l}\text { "Easy and convenient. It's an all in one } \\
\text { app for legal and Emergency situations" }\end{array}$ & $\begin{array}{l}\text { "Useless app. this app take your information to } \\
\text { provide legal advisor but nobody responds" }\end{array}$ & Yes \\
\hline & & $\begin{array}{l}\text { "Great piece of mind knowing Love this } \\
\text { App!" }\end{array}$ & "Not too good" & Yes \\
\hline \multirow{2}{*}{$\begin{array}{l}\text { Introduction to } \\
\text { Law }\end{array}$} & \multirow{2}{*}{4.5} & $\begin{array}{l}\text { "It's okay and not too difficult to } \\
\text { understand" }\end{array}$ & "Not Good enough" & Yes \\
\hline & & $\begin{array}{l}\text { "This is the app people of today should } \\
\text { download" }\end{array}$ & -----. & Yes \\
\hline
\end{tabular}

TABLE. VIII. ONLINE AutomobILES Services APP ReVIEW

\begin{tabular}{|c|c|c|c|c|}
\hline $\begin{array}{l}\text { App Name } \\
{[39][40]}\end{array}$ & Rating & Positive Review & Negative Review & $\begin{array}{l}\text { Impact Upon Customer } \\
\text { Decision }\end{array}$ \\
\hline \multirow{2}{*}{ Uber } & \multirow{2}{*}{4.0} & $\begin{array}{l}\text { "My driver was very "professional and } \\
\text { polite". Uber is faster, economical and much } \\
\text { friendlier service than any of the local taxi" }\end{array}$ & $\begin{array}{l}\text { "When I order a uber, my phone says the driver will } \\
\text { arrive in } 5 \text { minutes, and ten minutes later, they still in } \\
\text { the same place" }\end{array}$ & Yes \\
\hline & & $\begin{array}{l}\text { "Overall, Uber is a great service, they } \\
\text { handle all complaints promptly" }\end{array}$ & $\begin{array}{l}\text { "Couldn't create an account because my 'number was } \\
\text { previously in use' even though my phone is new" }\end{array}$ & Yes \\
\hline \multirow{2}{*}{$\begin{array}{l}\text { Careem - Car } \\
\text { Booking App }\end{array}$} & \multirow{2}{*}{4.5} & $\begin{array}{l}\text { "Excellent service, excellent and } \\
\text { outstanding help via call service. } \\
\text { Complaints are responded quickly" }\end{array}$ & $\begin{array}{l}\text { "Very disappointed to use this service in Pakistan. } \\
\text { No option to give feedback on Careem" }\end{array}$ & Yes \\
\hline & & $\begin{array}{l}\text { "Great app!!!! But Not able to buy a } \\
\text { package now... There is an issue in } \\
\text { payment" }\end{array}$ & $\begin{array}{l}\text { "Extremely wretched app. The service is unpleasant. } \\
\text { No call center help is accessible. You have to chat } \\
\text { with a representative if u have an issue" }\end{array}$ & Yes \\
\hline \multirow{2}{*}{$\begin{array}{l}\text { TAXI Booking } \\
\text {-Cab Booking } \\
\text { App }\end{array}$} & \multirow[t]{2}{*}{3.1} & "Very good app" & $\begin{array}{l}\text { "A dirty app that I have ever seen Friends don't } \\
\text { download this app. It is just for show. I cannot book } \\
\text { any cab every time" }\end{array}$ & Yes \\
\hline & & "Like this app" & $\begin{array}{l}\text { "Don't download this app full waste of time and it } \\
\text { takes time to open" }\end{array}$ & Yes \\
\hline \multirow[t]{2}{*}{ AutoWala } & \multirow[t]{2}{*}{3.1} & $\begin{array}{l}\text { "It is very good it is very well I like this } \\
\text { because where I want to go the auto Wala } \\
\text { goes very good" }\end{array}$ & $\begin{array}{l}\text { "Not at all user-friendly. Not useful at the time of } \\
\text { need. I wish there should be zero ratings. ask plenty } \\
\text { of questions while registering and a problem with } \\
\text { location" }\end{array}$ & Yes \\
\hline & & "Best app for auto" & $\begin{array}{l}\text { "Please don't download this app, it's wastage of time. } \\
\text { This app is just meant to collect your info \& data } \\
\text { that's it" }\end{array}$ & Yes \\
\hline \multirow{2}{*}{$\begin{array}{l}\text { Cab Booking } \\
\text { Online All In } \\
\text { One }\end{array}$} & \multirow[b]{2}{*}{3.7} & $\begin{array}{l}\text { "Cars are very beautiful and wonderful and } \\
\text { clean" }\end{array}$ & $\begin{array}{l}\text { "Is there any option where I can put rating this is } \\
\text { time waste app" }\end{array}$ & Yes \\
\hline & & $\begin{array}{l}\text { "Great Cab booking online app! It simple } \\
\text { and has a nice UI and this has also saved my } \\
\text { device space" }\end{array}$ & "Worst of time fake app" & Yes \\
\hline
\end{tabular}


TABLE. IX. ONLINE Home SERvices APP REVIEW

\begin{tabular}{|c|c|c|c|c|}
\hline App Name & Rating & 'Positive Review & Negative Review & $\begin{array}{l}\text { Impact Upon Customer } \\
\text { Decision }\end{array}$ \\
\hline \multirow{2}{*}{$\begin{array}{l}\text { Doorstep Services } \\
\text { - Variety of Home } \\
\text { Services }\end{array}$} & \multirow[t]{2}{*}{3.8} & $\begin{array}{l}\text { "Awesome app for door services, easy to } \\
\text { use" }\end{array}$ & $\begin{array}{l}\text { "Wanted to fix the plumbing issue at my home. } \\
\text { My Bookings section does not show the booking. } \\
\text { Uninstalling it" }\end{array}$ & Yes \\
\hline & & $\begin{array}{l}\text { "Good app. } \\
\text { with best services" }\end{array}$ & $\begin{array}{l}\text { "I booked for refrigerator repairs, still it shown as } \\
\text { pending no response. Pathetic app and services" }\end{array}$ & Yes \\
\hline \multirow{2}{*}{$\begin{array}{l}\text { Service Guru: } \\
\text { Electrician, } \\
\text { Plumber, AC } \\
\text { Repair App }\end{array}$} & \multirow[b]{2}{*}{3.8} & $\begin{array}{l}\text { "Provide best services in all area \& create } \\
\text { customer care section" }\end{array}$ & "Waste no one is using this app" & Yes \\
\hline & & $\begin{array}{l}\text { "Your services are just awesome but } \\
\text { please provide your customer care } \\
\text { number so customers can do an inquiry } \\
\text { about rates of work" }\end{array}$ & "Not good app" & Yes \\
\hline \multirow{2}{*}{$\begin{array}{l}\text { House joy-Trusted } \\
\text { Home Services }\end{array}$} & \multirow[t]{2}{*}{3.6} & $\begin{array}{l}\text { "Good for getting maintenance and } \\
\text { cleaning work at home. } \\
\text { Best, smooth and appropriate" }\end{array}$ & $\begin{array}{l}\text { "Booked for Salon service (Mehendi) on the 4th } \\
\text { of august itself for } 11 \text { august did not get any } \\
\text { update. They call on } 11 \text { of August at 4:00 PM and } \\
\text { inform that they cannot fulfill the request" }\end{array}$ & Yes \\
\hline & & $\begin{array}{l}\text { "Provides salon services. Very Glad } \\
\text { about service. All the products used were } \\
\text { hygienically sealed and good quality" }\end{array}$ & $\begin{array}{l}\text { "Too bad experience. Raised a complaint about } \\
\text { bad repair service. And support informed that they } \\
\text { will get back in touch with me but no us" }\end{array}$ & Yes \\
\hline
\end{tabular}

\section{DISCUSSION}

For marketing different products and services different firms use social media platforms as it has more significant influence upon clients' decisions and judgments [9]. Online customer reviews and ratings are the prevalent sources of facts for clients who purchase goods from an unfamiliar or even from a familiar website [41]. The primary purpose of this study is to know the influence of products and services' reviews and scoring upon opinions of the people. The people consider the reviews more reliable and truthful than the recommendations by the professionals and paid experts. For this reason, the major contribution of this study is to explore the impact of the online consumer reviews and e-WOM, on purchasing decisions and hiring services. Fig. 2 elaborates the proposed framework of purchasing decision-making process including different steps and how these are influenced by social identity, optimism, undesirable E-WOM, trust and various individual and environmental factors.

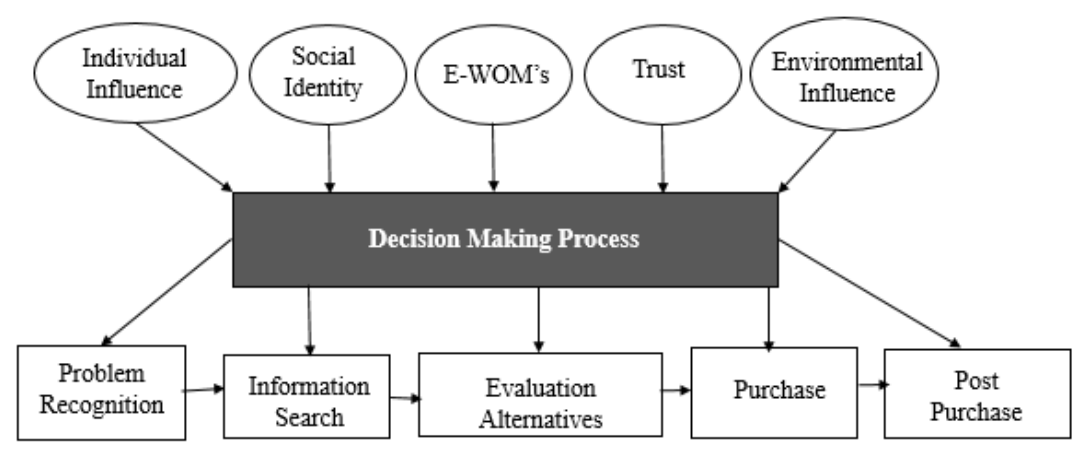

Fig. 2. Decision Making Process [42].

\section{CONCLUSION}

In nutshell, advancement of technology emerges a new advert of marketing phenomenon of online product review systems, which play a pivotal role in user's purchase decisions. This research work aims to evaluate the impact of e-WOM (electronic word-of-mouth) and online reviews on the user's buying behavior. A framework SOR is also discussed for evaluating the relation between consumer's purchase decisions and online reviews. According to this framework, the number of positive reviews impacts positively on the user's decision, neutral reviews do not influence the user and lastly, bad reviews put a negative impact on users' purchasing decisions. Furthermore, rapidly growing interconnected digital world brings an extensive pool of information via online reviews and consumers preferably rely on this information to eliminate the vulnerabilities of purchasing in a virtual environment. Nowadays, platforms like eBay and OLX have earned a great reputation from user's reviews and transparency in their systems. Customers mitigate the chance of uncertainty in purchasing by checking the past performance of sellers. However, this research work highlights the significance of user reviews across various categories of products and shown facts of different products, services, and applications. Lastly, in future, this research work can be extended and used for evaluating human social behavior on social networking platforms.

\section{REFERENCES}

[1] Baptista, J., A. D. Wilson, R. D. Galliers, and S. Bynghall. 2016. "Social Media and the Emergence of Reflexiveness as a New Capability for Open Strategy.” Long Range Planning 50 (3): 322-336. 
[2] Ngai, E. W. T., S. S. C. Tao, and K. K. L. Moon. 2015. "Social Media Research: Theories, Constructs, and Conceptual Frameworks." International Journal of Information Management 35 (1): 33-44.

[3] Saboo, A. R., V. Kumar, and G. Ramani. 2016. "Evaluating the Impact of Social Media Activities on Human Brand Sales." International Journal of Research in Marketing 33 (3): 524-541.

[4] Kristopher Floyd, Ryan Freling, Saad Alhoqail, Hyun Young Cho and Traci Freling, "How Online Product Reviews Affect Retail Sales: A Meta-analysis", Journal of Retailing, 2014.

[5] Pradeep Racherla, Wesley Friske,"Perceived 'usefulness' of online consumer reviews: An exploratory investigation across three services categories", Electronic Commerce Research and Applications 11(2012)548-559.

[6] Nawaz Ahmad, Jolita Vveinhardt, Rizwan Raheem Ahmed, "Impact of Word of Mouth on Consumer Buying Decision", European Journal of Business and Management, Vol.6, No.31, 2014.

[7] Kaynar, O., \& Amichai-Hamburger, Y. (2008). The effects of cognition on Internet use revisited. Computers in Human , 24(2), 361-371.

[8] Ali Yayli ,Murat Bayram,"Ewom: The effects of online consumer reviews on purchasing decision of electronic goods".

[9] Smita Dayal, "An analysis of social media influence on online behaviour of Indian customers". XVII International Seminar Proceedings,2016, 887-906.

[10] Zan Mo, Yan-Fei Li \& Feng Fan, "Effect of online reviews on consumer purchase behaviour", Journal of Service Science and Management,2015, pp. 419-424.

[11] Prabha Kiran, Vasantha S," Review article- Exploring the impact of online reviews on purchase intentions of customer", American International Journal of Research in Humanities, Arts \&Social Sciences, 2015, pp.211-214.

[12] Simona Vinerean, Iuliana Cetina, Luigi Dumitrescu \& Mihai Tichindelean (2013). The effects of social media marketing on online consumer behaviour. International Journal of Business and Management, 8(14), PP.66-78.

[13] Shashank Kumar Chauhan, Anupam Goel, Prafull Goel, Avishkar Chauhan and Mahendra K Gurve, "Research on Product Review Analysis and Spam Review Detection", 2017.

[14] Antila, Sara.( 2016). Brand awareness research Case: TravelBird.

[15] Karam,A.A. Saydam,S.( 2015,January). An Analysis Study of Improving Brand Awareness and Its Impact on Consumer Behavior Via Media in North Cyprus (A Case Study of Fast Food Restaurants). International Journal of Business and Social Science Vol. 6, No. 1.

[16] Thomas Ngo-Ye, "Ebay or Craigslist?: Explaining Users' Choice of Online Transaction Community",Issues in Information Systems Volume 14, Issue 2, pp.382-392, 2013.

[17] Prof.Manjunath.G.( 2015). Brand Awareness and Customers Satisfaction towards OLA Cabs in Bengaluru North and South Region. Research journal of social science and management.

[18] Khade,A.A. \& Dr. Patil,V.(2018). A study of customer satisfaction level of ola and uber paid taxi aservices with special reference to pune city.International Journal of Management, Technology And Engineering.

[19] Sangkil Moon, Paul K. Bergey, \& Dawn Iacobucci "Dynamic Effects Among Movie Ratings,Movie Revenues, andViewer Satisfaction”,Journal of Marketing Vol. 74 (January 2010), 108-121.

[20] Michael Luca, "Reviews,Reputation and Revenue:The case of Yelp.com", 2016.

[21] Luís Pacheco, "An analysis of online reviews of upscale Iberian restaurants", Multidisciplinary e- Journal, 2018.

[22] Nefike Gunden, "How Online Reviews Influence Consumer Restaurant Selection”,2017.
[23] Dr. Ramazan GÖRAL , Simge TOKAY, " Online Customer Reviews on Restaurants and Expert Opinions: An Integrated Approach", European Journal of Interdisciplinary Studies May-August 2015 Volume 1, Issue 2 .

[24] Woo Gon Kim, Jun (Justin) Li, Robert A. Brymer, "The impact of social media reviews on restaurant performance:The moderating role of excellence certificate", International Journal of Hospitality Management 55 (2016) 41-51.

[25] Julie Zhang, Qiang Ye, Rob Law, Yijun Li , “ The impact of e-wordof-mouth on the online popularity of restaurants: A comparison of consumer reviews and editor reviews", International Journal of Hospitality Management · December 2010.

[26] Chevalier, J., and Mayzlin, D. The effect of word of mouth online: online book reviews. Journal of Marketing Research, 43, 3, 2006, 345 354.

[27] Mudambi, S., and Schuff, D. What makes a helpful online review? MIS Quarterly, 34,1, 2010, 185-200.

[28] Yang, J., and Mai, E. Experiential goods with network externalities effects: an empirical study of online rating system. Journal of Business Research, 63, 9-10, 2010, 1050-1057.

[29] Park, C. and Lee, T.M. (2009) Information Direction, Website Reputation and eWOM Effect: A Moderating Role of Product Type. Journal of Business Research, 62, 61-67.

[30] Mudambi, S.M. and Schuff, D. (2010) What Makes a Helpful Review? A Study of Customer Reviews on Amazon. com. MIS Quarterly, 34, 185-200.

[31] Duan, W.J., Gu, B. and Whinston, A.B. (2008) The Dynamics of Online Word-of-Mouth and Product Sale An Empirical Investigation of the Movie Industry. Journal of Retailing, 84, 233-242.

[32] Mehrabian, A. and Russell, J.A. (1974) An Approach to Environmental Psychology. The MIT Press, Cambridge.

[33] Christopher Cheney,April 29, 2019.[online].Available at "https://www.healthleadersmedia.com/clinical-care/70-patients-callonline-reviews-crucial-selecting-healthcare-providers", Accessed on 02, Feb.2020.

[34] Andrew Ibbotson, 26 Nov,2018. [online].Available at "https://nrchealth.com/patients-trust-online-reviews/", Accessed on 02, Feb.2020.

[35] Shannon Woodworth And Tuesday Wilson,17 Dec,2018[online].Available at "https://www.nextech.com/blog/onlinereviews", , Accessed on 02, Feb.2020.

[36] https://broadly.com/blog/online-reviews-for-lawyers/

[37] Cristopher Bryant, 17 Dec,2016,[online].Available at "https://www.martindale.com/marketyourfirm/blog/the-importance-ofclient-reviews-for-attorneys/", Accessed on 02, Feb.2020.

[38] Online Reviews For Lawyers, [online].Available at "https://www.acceleratenow.com/law-firm-review-management/". Accessed on 02, Feb.2020.

[39] Caraoline O' Donovan, 11 April,2017,[online].Available at "https://www.buzzfeednews.com/article/carolineodonovan/the-fault-infive-stars", , Accessed on 02, Feb.2020.

[40] Aric Jeniks, 5 April,2018,[online].Available at "https://fortune.com/2018/04/05/uber-negative-ratings-stars/", Accessed on 02, Feb.2020.

[41] Feng Zhu \& Xiaoquan Zhang (2010). Impact of online consumer reviews on sales: The moderating role of product andconsumer characteristics. Journal of Marketing, 74, pp.133-148.

[42] Nawaz Ahmad, Jolita Vveinhardt, Rizwan Raheem Ahmed, "Impact of Word of Mouth on Consumer Buying Decision", European Journal of Business and Management, Vol.6, No.31, 2014. 